\title{
PENGGUNAAN SALAM SEBAGAI UNGKAPAN SAPAAN DALAM DRAMA SEIGI NO MIKATA DAN OHITORISAMA
}

\section{Use of Greetings as A Discussion in Inside Drama Seigi No Mikata And Ohitorisama}

\author{
Utami Sulistyaningrum \\ Program Studi Magister Ilmu Linguistik \\ Fakultas Ilmu Budaya Universitas Jember \\ Pos-el: utamimichan91@ gmail.com \\ tanggal naskah masuk 14 Agustus 2018 \\ tanggal akhir penyuntingan 29 November 2018
}

\begin{abstract}
Regards is an expression that can be used to greet someone. In Japanese society, greetings vary greatly depending on each user. This study aims to describe the types of greetings, domains and factors of use of the greeting phrase. The data sources used are two Japaneselanguage drama scripts titled Seigi no mikata and Ohitorisama. The data is analyzed qualitatively by using the qualitative method, referentially equivalent, and pragmatically matched. The theories used are sociopragmatic theory, Brown and Levince politeness strategies, power and distance, and aisatsu 'greetings'. Based on the results of the analysis there are 14 types of greetings as greeting expressions, for example: ohayou gozaimasu, konnichiwa, konbanwa, etc. The variations in the greeting expressions are influenced by factors related to the opponent's speech, time, place, and the situation / event of speech. While the politeness strategy that is often used is direct politeness strategy without further ado. Based on the results of the analysis, it was concluded that as regards the variation of greetings as a greeting in Japanese is very dependent on the existence of the situation and context of a speech.
\end{abstract}

Keywords: aisatsu 'regards', greeting, politeness, sociopragmatic strategy

\section{Abstrak}

Salam merupakan sebuah ungkapan yang dapat digunakan untuk menyapa seseorang. Dalam tuturan masyarakat Jepang, salam sangatlah bervariasi bergantung pada setiap penggunanya. Penelitian ini bertujuan untuk mendeskripsikan jenis-jenis salam, ranah dan faktor penggunaan ungkapan sapaan tersebut. Adapun sumber data yang digunakan ialah dua buah naskah drama berbahasa Jepang berjudul Seigi no mikata dan Ohitorisama. Data tersebut dianalis secara deskriptif kualitatif dengan metode agih, padan referensial, dan padan pragmatis. Teori yang digunakan ialah teori sosiopragmatik, strategi kesantunan Brown dan Levince, power and distance, dan aisatsu 'salam'. Berdasarkan hasil analisis terdapat 14 jenis salam sebagai ungkapan sapaan, misal: ohayou gozaimasu, konnichiwa, konbanwa, dll. Adapun variasi ungkapan sapaan tersebut, dipengaruhi oleh faktor yang berkaitan dengan lawan tutur, waktu, tempat, dan situasi/peristiwa tutur. Sedangkan strategi kesantunan yang sering digunakan ialah strategi kesantunan langsung tanpa basa-basi. Berdasarkan hasil analisis tersebut, disimpulkan bahwa adapun variasi salam sebagai ungkapan sapaan dalam bahasa Jepang ialah sangat bergantung dengan adanya situasi dan konteks sebuah tuturan.

Kata-kata kunci: aisatsu 'salam', sapaan, strategi kesantunan, sosiopragmatik

\section{PENDAHULUAN}

Salam merupakan suatu kegiatan yang paling sederhana dalam kegiatan berkomunikasi. Dalam bahasa Jepang, salam dikenal dengan istilah aisatsu [aisatsu] (Matsuura,1994:5). Penggunaan salam juga sangat dipengaruhi oleh adanya budaya, situasi, dan juga dapat berubah akibat status dan hubungan sosial. Salam dapat diekspresikan melalui ucapan dan gerakan atau gabungan dari keduanya. Salam dapat berfungsi sebagai ungkapan 
sapaan yang dapat digunakan untuk menyapa atau mengajak seseorang untuk berbicara. Dalam Kamus Besar Bahasa Indonesia, sapaan diartikan sebagai suatu ajakan untuk bercakap, teguran, atau ucapan. Secara linguistik, sapaan ialah kata atau frasa untuk saling merujuk dalam pembicaraan yang berbeda-beda menurut sifat hubungan di antara pembicara itu, seperti anda, ibu, atau saudara. Sapaan juga dapat berupa ungkapan salam yang ditujukan pada seseorang (kbbi.web.id/ sapa). Pengertian yang sama juga diungkapkan oleh Kridalaksana (1982:14), yaitu sapaan merupakan suatu ungkapan yang merujuk pada kata atau ungkapan yang dipakai untuk menyambut, memanggil, atau menyebut para pelaku dalam suatu peristiwa bahasa.

Penggunaan salam dalam tuturan masyarakat Jepang, sangatlah bervariasi bergantung dengan situasi dan konteks tuturannya. Adanya variasi ungkapan salam tersebut dipengaruhi oleh banyak faktor, termasuk faktor kekerabatan yang nantinya akan mempengaruhi adanya tingkat kesantunan tuturan tersebut. Hal ini membuat peneliti tertarik untuk meneliti penggunaan salam sebagai ungkapan sapaan dalam drama berbahasa Jepang. Drama merupakan salah satu gambaran tentang kehidupan suatu kelompok masyarakat. Alasan dipilihnya dua buah drama yang berjudul Seigi no mikata dan Ohitorisama ialah sebagai bahan pembanding yang mana pada kedua drama tersebut menceritakan tentang kehidupan masyarakat Jepang yang natural dan tidak dibuat-buat. Selain itu, banyaknya situasi dan konteks tuturan dalam drama tersebut yang dapat mendukung adanya penggunaan ungkapan sapaan dalam masyarakat Jepang. Berdasarkan latar belakang tersebut, muncullah tiga permasalahan mengenai salam sebagai ungkapan sapaan pada tuturan masyarakat Jepang dalam drama Seigi no mikata dan Ohitorisama, yaitu: jenis-jenis salam, ranah penggunaan dan faktor penggunaan salam sebagai ungkapan sapaan.

\section{LANDASAN TEORI}

\section{Salam Dalam Bahasa Jepang}

Salam merupakan bagian awal dari kegiatan berkomunikasi, maka dari itu salam sangat berperan penting dalam kehidupan sehari-hari. Adanya suatu bahasa juga dapat mempengaruhi adanya suatu kegiatan berkomunikasi. Suatu kegiatan komunikasi dapat terjadi dengan baik dengan adanya suatu bahasa yang digunakan oleh setiap invidu dengan sesamanya. Dalam tuturan masyarakat Jepang, salam dikenal dengan istilah aisatsu. Menurut Matsuura, aisatsu atau dapat diartikan sebagai salam, sapaan, ucapan, dan sambutan (1994:5). Aisatsu juga berarti kata atau tindakan yang dilakukan ketika bertemu dan berpisah dengan seseorang. Menurut Nomoto (1994:11), definisi aisatsu dapat dijabarkan sebagai berikut:

1. Salam, artinya apabila kita bertemu seseorang di pagi hari kita memberi salam dengan mengucapkan selamat pagi, lalu memberi salam dengan membungkukkan badan.

2. Merupakan sambutan yang diucapkan pada upacara atau pertemuan, misalnya seperti pidato pembukaan.

3. Penyampaian secara resmi agar diketahui pihak lain mengenai perubahan yang terjadi pada diri sendiri dan sebagainya.

4. Balasan, jawaban penerimaan, pelayanan.

Aisatsu atau salam merupakan suatu komunikasi yang sering kali digunakan dalam kegiatan sehari-hari, khususnya sebagai salam pembuka dan penutup dari sebuah percakapan atau dialog, dan juga memperkenalkan kepada suatu topik yang akan dibahas. Mizutani (1979:63) juga menyatakan fungsi dari adanya salam dalam kehidupan sehari-hari, seperti misalnya ialah untuk menjaga kelancaran dalam suatu pergaulan. Pada intinya yang perlu untuk ditekankan dari fungsi salam bukanlah untuk membuat suatu hubungan baru dengan seseorang, melainkan untuk lebih menjaga hubungan 
yang selama ini telah dibangun. Adapun ungkapan salam yang diucapkan misalnya おはようございます[ohayou gozaimasu] ketika di pagi hari, こんにちは [konnichiwa] ketika di siang hari, こんば んは [konbanwa] di malam hari, dan lain sebagainya.

\section{Teori Kesantunan}

\section{a. Strategi Kesantunan}

Brown dan Levinson memaparkan bahwa terdapat 5 strategi kesantunan yaitu sebagai berikut.

1.) Strategi Kesantunan Langsung Tanpa Basa-Basi

Strategi kesantunan langsung tanpa basa-basi merupakan suatu strategi dalam bertutur sapa dengan melakukan suatu tindakan untuk menyatakan sesuatu dengan jelas. Strategi ini dipilih dikarenakan penutur ingin mengutarakan maksud dan tujuannya secara maksimum. Alasan lainnya ialah dimana keadaan atau situasi tuturan tersebut menjadi penyebab dipilihnya strategi ini (Brown dan Levinson, 1987:63).

\section{2.) Strategi Kesantunan Positif}

Strategi kesantunan positif merupakan strategi atau cara untuk melakukan suatu peritiwa tutur dengan cara menjaga muka positif mitra tuturnya. Muka positif yang dimaksudkan ialah sebuah citra diri atau martabat dari mitra tutur mengenai adanya nilai solidaritas, ketidakformalan, dan rasa ingin untuk diakui baik oleh seseorang (Brown dan Levinson, 1987:65) . 3.) Strategi Kesantunan Negatif

Strategi kesantunan negatif merupakan salah satu jenis strategi yang digunakan untuk dapat menyelamatkan atau menjaga muka negatif mitra tutur. Strategi ini bertujuan untuk mempertahankan kebebasan bertindak mitra tutur. Muka negatif yang dimaksudkan ialah pada citra diri mitra tutur untuk melakukan tindakan secara bebas tanpa adanya tekanan dari pihak lain (Brown dan Levinson, 1987:65).

4.) Strategi Kesantunan Tidak Langsung

Strategi kesantunan yang keempat ialah strategi kesantunan tidak langsung.
Strategi ini merupakan suatu strategi penggunaan tuturan yang secara tidak langsung dengan cara membiarkan mitra tutur untuk dapat mengambil keputusannya sendiri atau menafsirkan sendiri maksud dari tuturan si penutur (Brown dan Levinson, 1987:211).

5.) Strategi Kesantunan Bertutur Dalam Hati

Menurut Brown dan Levinson (1987:227) strategi kesantunan yang terakhir ini ialah merupakan suatu strategi kesantunan yang dilakukan oleh si penutur tanpa melakukan suatu tuturan dengan mitra tuturnya.

\section{b. Power and Distance}

Istilah Power dapat dimaksudkan sebagai umur dan status sosial dari penutur dan mitra tuturnya. Adanya perbedaan umur antara penutur dan mitra tutur dapat memengaruhi adanya penggunaan katakata atau bahasa. Sedangkan distance adalah solidaritas, kekerabatan, atau keintiman antara penutur dan mitra tutur. Dalam linguistik bahasa Jepang istilah Distance juga dapat berupa uchi (di dalam grup) dan soto (di luar grup) (Usami, 2002:5).

Menurut Makino (1996:10) yang dimaksud dengan uchi adalah tempat yang paling mengelilingi penutur, keluarga, di dalam rumah, orang yang memiliki keturunan langsung, kerabat, hal-hal yang bersifat pribadi. Sedangkan soto adalah lawan dari uchi, yaitu berada di luar rumah, orang yang tidak termasuk ke dalam anggota keluarga. Dalam artian yang lebih luas, uchi dapat berarti seseorang yang berada di dalam satu lingkup, tidak hanya lingkup keluarga, melainkan lingkup sekolah, tempat kerja dan sebagainya. Misalnya dalam perusahaan. Hubungan uchi-soto ini diperjelas oleh Hirabayashi dkk (1992:3) bahwa adanya pemakaian bahasa formal atau sopan umumnya tidaklah digunakan dalam lingkup orang yang mempunyai hubungan dekat atau orang dalam (uchi no hito). Sedangkan jika berbicara dengan orang yang kurang 
mempunyai hubungan dekat (soto no hito), maka orang Jepang akan menghormati orang tersebut dengan cara menggunakan bahas formal atau sopan. Hal ini bertujuan juga untuk menjaga adanya tingkat kesopanan antara penutur dan mitra tutur.

Menurut Marjory dkk (dalam Niyekawa, 1991:38) bahasa yang digunakan oleh seorang penutur dapat merefleksikan hubungan kekuasaan (power) dan solidaritas (distance) dari si penutur dan mitra tutur. Niyekawa menyatakan bahwa berdasarkan hubungan power dan distance antara penutur dan mitra tutur, ragam bahasa dapat dibedakan menjadi 2, yaitu ragam bahasa formal yang ditandai dengan ーです [ d dssu]・ます[masu], dan ragam bahasa informal yang ditandai dengan bentuk -だ $[\sim d a]$. Kepada seseorang yang memiliki hubungan kekerabatan atau solidaritas (distance) yang dekat dengan penutur biasanya akan digunakan ragam bahasa informal, misalnya kepada teman, keluarga, dan semacamnya. Sebaliknya kepada seseorang atau mitra tutur yang memiliki hubungan kekerabatan atau solidaritas yang jauh, dan juga kepada seseorang yang kedudukan (power) lebih tinggi daripada penutur, lebih banyak digunakan ragam bahasa formal. Berdasarkan yang dikemukakan oleh Hosmes (2001:9) bahwa adanya status dapat memengaruhi adanya pemakaiaan bahasa dalam suatu lingkup sosial. Mizutani (1983:248) juga mengemukakan mengenai adanya pengucapan pada aisatsu dapat berubah sesuai dengan mitra tutur yang akan diajak oleh penutur untuk berbicara.

\section{METODE PENELITIAN}

Pada penelitian ini, data diperoleh dari naskah drama Seigi no mikata dan Ohitorisama. Data tersebut diperoleh dengan metode simak yakni teknik Simak Bebas Libat Cakap (SBLC) dilanjutkan dengan teknik catat. Adapun data temuan tersebut dianalisis dengan metode agih yakni teknik Bagi Unsur Langsung (BUL) dilanjutkan dengan teknik ganti dan metode padan referensial pada rumusan masalah pertama terkait dengan jenis-jenis ungkapan sapaan. Kemudian dilanjutkan dengan metode padan pragmatis pada rumusan masalah kedua dan ketiga terkait dengan ranah penggunaan dan faktor yang mempengaruhi penggunaan ungkapan sapaan dalam tuturan masyarakat Jepang.

\section{HASIL ANALISIS DAN PEMBAHASAN}

Variasi salam sebagai ungkapan sapaan yang digunakan dalam drama Seigi no mikata dan Ohitorisama yaitu sebagai berikut:

(1) Ohayou gozaimasu / Ohayou

Konteks: ketika Guru Akiyama tiba di sekolah pada pagi hari, beberapa siswa menyapanya dengan mengucapkan salam selamat pagi

$\begin{array}{ll}\text { 生徒達 } & \text { ：おはよう } \\ \text { ございます } & \\ \text { 秋山先生 } & \text { ： おはよう } \\ \text { <Seito tachi> } & \end{array}$

<Ohayou gozaimasu>

[scito taci]

[ohayo: gozaimas]

'siswa'

'selamat pagi'

$<$ Ohayou $>$

<Akiyama sensei> :

[ohayo:]

[akiyama sense]

\section{'pagi'}

'guru Akiyama'

(Ohitorisama, episode 1 menit ke-1:28)

Ohayou gozaimasu merupakan sapaan salam yang berartikan 'selamat pagi' dalam bahasa Indonesia. Pada data percakapan di atas, sapaan ini digunakan oleh para siswa pada gurunya yang bernama Akiyama. Bersituasikan ketika Guru Akiyama tiba di sekolah pada pagi hari, beberapa siswa menyapanya dengan mengucapkan salam selamat pagi. Salam ini biasanya digunakan untuk menyapa seseorang pertama kali di pagi hari. Sapaan selamat pagi ini dituturkan dalam bentuk formal oleh para murid pada gurunya. Sedangkan sang guru membalas 
salam sapaan para murid dengan sapaan ohayou. Ohayou ialah sapaan salam non formal dari salam ohayou gozaimasu. Kedua salam tersebut dapat dituturkan oleh siapapun bergantung dari situasi tuturan tersebut. Salam ohayou gozaimasu biasanya akan dituturkan pada seseorang yang lebih tua atau memiliki status sosial yang lebih tinggi. Sedangkan pada salam ohayou biasanya akan dituturkan kepada lawan tutur yang sudah dikenal akrab seperti sesama anggota keluarga, teman, atau pada seseorang yang lebih muda.

(2) Konnichiwa

Konteks: ketika seorang manager sebuah toko sedang berbicara dengan Youko, tiba-tiba ada salah satu pelanggan yang datang.

$$
\begin{array}{ll}
\text { マネージャー： あっこんにちは！ } \\
\text { 文香 } & \text { : こんにちは。 } \\
\text { <Maneeja }> & :<A^{\prime}
\end{array}
$$

konnichiwa!>

$\begin{array}{ll}\text { [mane:ja] } & \begin{array}{l}\text { [a? Konniciwa] } \\ \text { 'manejer' }\end{array} \\ \text { 'Selamat siang' } \\ \text { [ Fumika> } & \begin{array}{l}\text { <Konnichiwa }> \\ \text { [konnika }]\end{array} \\ & \text { 'Selamat siang' }\end{array}$

(Seigo no mikata, episode 5 menit ke35:08)

Konnichiwa merupakan sapaan berupa salam yang berartikan 'selamat siang' dalam bahasa Indonesia. Pada umumnya sapaan ini biasanya dituturkan oleh masyarakat Jepang di siang hari. Pada data percakapan di atas, sapaan konnichiwa di gunakan oleh seorang manejer sebuah weeding organizer pada salah satu pelanggannya yang bernama Fumika. Bersituasikan ketika seorang manager sebuah toko sedang berbicara dengan Youko, tiba-tiba ada salah satu pelanggan yang datang dan manager tersebut menyambutnya dengan sapaan konnichiwa. Adapun salam balasan dari sapaan konnichiwa, ialah mengulang kembali sapaan konnichiwa, seperti yang dicontohkan oleh Fumika dalam percakapan tersebut. Sapaan konnichiwa juga dapat menggantikan sapaan 'hai' dalam tuturan masyarakat Jepang.

\section{Konbanwa}

Konteks: ketika Akiyama baru saja pulang dari bekerja di malam hari, tiba-tiba saja ia bertemu dengan tetangganya dan mengucapkan salam.

$$
\text { 秋山:こんばんは〜 }
$$

隣人: こんばんは

あッ秋山さん＼cjkstart秋山さん

\section{$<$ Akiyama $>:<$ Konbanwa $>$ [akiyama] \\ [kombaywa] \\ 'Selamat malam' \\ $<$ Rinjin> : <Konbanwa \\ A' Akiyama san akiyama san> [rinjin]}

[kombaywa

a? akiyama san akiyama

say]

\section{'Tetangga'}

'Selamat malam

Eeh nona Akiyama nona Akiyama'

(Ohitorisama, episode 2 menit ke-13:40)

Konbanwa merupakan sapaan salam yang berartikan 'selamat malam' dalam bahasa Indonesia. Pada umumnya sapaan ini biasanya digunakan oleh masyarakat Jepang di malam hari. Berdasarkan pada data percakapan di atas, sapaan salam konbanwa digunakan oleh seorang tetangga pada tetangga apartemennya yang bernama Akiyama. Bersituasikan Akiyama baru saja pulang dari bekerja di malam hari, tiba-tiba saja ia bertemu dengan tetangganya dan mengucapkan salam konbanwa. Sama halnya dengan sapaan konnichiwa, salam jawaban untuk sapaan konbanwa juga mengulang kembali sapaan tersebut. Seperti yang ditunjukkan oleh tetangga setelah ia mendapatkan salam tersebut dari Akiyama. Dalam tuturan masyarakat Jepang sangatlah penting untuk merespon adanya sapaan salam yang diberikan oleh seseorang. Hal ini dibutuhkan untuk tetap menjaga adanya suatu komunikasi yang 
baik antara si penutur dan mitra tutur. Selain itu respon sapaan salam yang diberikan juga dapat memberikan kesan ramah dan bersahabat pada si penutur.

(4) Irrashaimase / Rassai

Konteks: ketika Kamisaka sedang bekerja untuk mengecek stok-stok barang yang telah kosong, tiba-tiba ia melihat ada pelanggan yang baru datang dan menyambut dengan sapaan salam irasshaimase.

上坂 : いらっしやいませ

<Kamisaka>: <Irasshaimase>

[kamisaka] [ira aimase]

'Selamat datang'

(Ohitorisama, episode 1 menit ke- 2:44)

Irasshaimase merupakan sebuah sapaan salam yang berartikan 'selamat datang' dalam bahasa Indonesia. Sapaan salam ini sering kali terdengar di tempattempat perbelanjaan seperti supermarket, pasar, restoran, dan tempat perbelanjaan lainnya. Sapaan ini biasanya digunakan untuk menyambut para pelanggan yang datang. Seperti pada data percakapan di atas, sapaan ini digunakan oleh seorang pelayan supermarket pada para pelanggan yang datang berkunjung. Bersituasikan ketika Kamisaka sedang bekerja untuk mengecek stok-stok barang yang telah kosong, tiba-tiba ia melihat ada pelanggan yang baru datang dan menyambut dengan sapaan salam irasshaimase. Salam irasshaimase dapat dituturkan dengan bentuk salam yang lebih pendek yaitu rassai. Meskipun terdapat perbedaan dari cara penuturan sapaan tersebut, namun keduanya memiliki pengertian yang sama yaitu selamat datang.

(5) Itte mairimasu / Itte kuruyo

Konteks: ketika ibu sedang mempersiapkan sarapan di pagi hari, tiba-tiba Makiko menyapanya dengan langsung berpamitan pergi ke kantor.

真紀子:いってまいります。
お母さん：ん。おね

えちゃん食べないの?

$<$ Makiko> : <Itte mairimasu>

[makiko] [itt $\varepsilon$ mairimas]

'Aku berangkat dulu'

<Okaasan> : $\quad<\mathrm{Hmm}$..

Oneechan tabenaino ?>

[oka:say] [y..

one:cay tabenaino]

'Ibu' 'Hmm..

Kakak enggak makan dulu?'

(Seigi no mikata, episode 5 menit ke$12: 24)$

Itte mairimasu merupakan sapaan salam yang berartikan 'aku berangkat dulu' dalam bahasa Indonesia. Salam ini biasanya digunakan oleh masyarakat tutur Jepang ketika ia hendak pergi keluar rumah untuk bekerja atau bersekolah di pagi hari. Pada data percakapan di atas, sapaan salam ini digunakan oleh seorang anak bernama Makiko pada ibunya. Bersituasikan ketika ibu sedang mempersiapkan sarapan di pagi hari, tibatiba Makiko menyapanya dengan langsung berpamitan pergi ke kantor.

Salam itte mairimasu biasanya digunakan oleh anggota keluarga yang akan pergi dengan maksud untuk menginformasikan pada anggota keluarga yang berada di rumah jika ia akan pergi keluar rumah. Sapaan ini merupakan bentuk sopan dari sapaan itte kimasu. Sapaan itte kimasu juga memiliki sapaan non formalnya yaitu itte kuruyo. Meskipun terdapat perbedaan dalam penuturannya, sapaan-sapaan tersebut memiliki pengertian yang sama. Perbedaannya terletak pada tingkat kesantunan saja. Sapaan itte kuruyo terdengar lebih akrab jika diucapkan oleh sesama anggota keluarga.

(6) Tadaima / Tadaima kaerimashita

Konteks: ketika seorang anak baru saja pulang dari sekolah dan berusaha untuk menyapa semua keluarganya, yang mana pada saat itu sedang berkumpul di dapur rumah.

容子: ただいま 


\author{
お母さん：おかえり \\ <Youko> : \\ $<$ Tadaima $>$ \\ [yo:ko] [tadaima] \\ 'Aku pulang' \\ <Okaasan> : <Okaeri>
[oka:say] [okacri] \\ 'Selamat datang' \\ (Seigi no mikata, episode 2 menit ke-
} 25:17)

Tadaima merupakan sapaan salam yang memiliki makna 'aku pulang' atau 'saya sudah kembali' dalam bahasa Indonesia. Pada data percakapan di atas, ungkapan sapaan salam tadaima diucapkan oleh penutur Youko pada ibunya dengan maksud untuk menyapa seluruh keluarganya. Bersituasikan ketika seorang anak baru saja pulang dari sekolah dan berusaha untuk menyapa semua keluarganya, yang mana pada saat itu sedang berkumpul di dapur rumah. Menurut Chin (2003:202) salam tadaima memiliki arti 'baru saja' atau 'sekarang'. Ungkapan salam tersebut wajib untuk diucapkan oleh salah satu anggota keluarga yang baru saja pulang dari bepergian. Jika dibandingkan dengan bahasa Indonesia, ungkapan tadaima ini dapat menggantikan ungkapan salam assalamualaikum yang mana menjadi salah satu salam kebiasaan masyarakat muslim pada umumnya di Indonesia. Sapaan ini juga memiliki bentuk panjang dalam variasi penuturannya yaitu tadaima kaerimashita.

(7) Okaeri

Konteks: ketika ibu melihat Youko dan Taichi pulang sekolah dari kejauhan, ibupun menyapa mereka berdua. 春子： おかえり！ 洋子： ただいま。 <Haruko> : <Okaeri !> [harwko]

[okaeri] 'Selamat datang!'

<Youko> : <Tadaima>

[yo:ko] [tadaima]

'Aku pulang'
(Seigi no mikata, episode 1 menit ke$14: 22)$

Okaeri sesungguhnya merupakan salam jawaban dari salam tadaima. Salam jawaban okaeri dapat bermaknakan 'selamat datang' atau 'selamat kembali ke rumah' dalam bahasa Indonesia. Salam jawaban ini akan dituturkan oleh anggota keluarga yang berada di dalam rumah setelah ia mendengar salam tadaima diucapkan. Namun kenyataan yang terlihat pada contoh data percakapan di atas yaitu salam jawaban ini digunakan untuk menyapa mitra tuturnya. Pada data percakapan tersebut, salam tersebut digunakan oleh seorang ibu pada anaknya yang baru saja pulang dari sekolah. Bersituasikan ketika sang ibu melihat Youko dan Taichi pulang sekolah dari kejauhan, ibupun menyapa mereka berdua dengan sapaan okaeri.

(8) Ojama shiterundane

Konteks: ketika orang tua Yoshikawa dan orang tua Nakata sedang berdebat, tiba-tiba Yoshikawa datang untuk melerai mereka.

洋子：良川さん！

良川： お邪魔して

るんだね失礼するよ。

<Youko> : <Yoshikawa san!>

[yo:ko] [yofikawa say]

'Tuan Yoshikawa!'

$<$ Yoshikawa $>$ :

$<$ Ojama shiterundane

shitsurei suruyo $>$ [yofikawa] [ojama Jiterundane Jitsurei suruyo]

'Maaf

permisi y $a$ '

mengganggu,

(Seigi no mikata, episode 5 menit ke 30:42)

Ojama shiterundane merupakan sapaan salam yang berartikan 'maaf mengganggu' dalam bahasa Indonesia. Pada data percakapan di atas, sapaan salam ini digunakan oleh seorang penutur bernama Yoshikawa pada Youko. Bersituasikan ketika orang tua Yoshikawa 
dan orang tua Nakata sedang terdebat, tiba-tiba Yoshikawa datang untuk melerai mereka. Sebelum memasuki rumah ia mengucapkan salam ojama shiterundane pada Youko. Sapaan salam ini biasa digunakan oleh seorang penutur bahasa Jepang ketika akan memasuki rumah seseorang. Salam yang dituturkan Yoshikawa ini terdengar santun dan terkesan sangat menghargai sang pemilik rumah.

(9) Sumimasen / Suimasen

Konteks: ketika Youko berniat akan membeli sebuah tiket konser musik pada seorang penerima tamu di sebuah gedung teater.

洋子: あのすいません 今の方の隣の席っ て空いてますか?

$<$ Youko $>$ : <Ano

\section{suimasen}

Ima no hou no tonari no sekitte aitemasuka ?>

[yo:ko] [ano: suwimasen

ima no ho no tonari no sekitte

aitemaska]

'hmm maaf permisi

Apakah ada kursi yang tersedia

di sebelah orang itu?'

(Seigi no mikata, episode 2 menit ke 9:54)

Sumimasen/suimasen merupakan sapaan salam yang bermaknakan 'permisi' dalam bahasa Indonesia. Sapaan salam ini sesungguhnya yang benar ialah sumimasen, namun banyak masyarakat tutur Jepang yang menuturkannya dengan suimasen. Hal ini dikarenakan adanya kecepatan ketika mereka menuturkannya, membuat salam tersebut terdengar seperti suimasen. Hal yang sama juga terjadi pada contoh data percakapan di atas. Suimasen digunakan oleh seorang penutur bernama Youko pada seorang penerima tamu sebuah konser. Bersituasikan ketika Youko berniat akan membeli sebuah tiket konser musik pada seorang penerima tamu di sebuah gedung teater.

Dalam masyarakat tutur Jepang, sapaan ini termasuk sapaan salam yang sering digunakan dalam segala aktifitas sehari-hari. Penyebabnya ialah pada salam tersebut tidak hanya berartikan 'permisi' saja, melainkan dapat pula bermakna 'maaf' atau 'terima kasih'. Hal ini bergantung pada situasi dan konteks tuturan tersebut. Jika sapaan sumimasen/ suimasen dituturkan di awal percakapan, maka dapat bermaknakan 'permisi' atau 'maaf'. Sebaliknya jika sapaan ini dituturkan di akhir kalimat dan didukung dengan adanya situasi, maka dapat bermaknakan 'terima kasih'.

(10) Shitsurei shimasu / Shitsurei suruyo Konteks: ketika guru Kamisaka berniat untuk bertemu dengan kepala sekolah di ruangannya, ia pun mengetuk pintu dan tidak lama kepala sekolah pun mengizinkannya masuk.

(ノック) (suara ketukan pintu)

校長先生: はい

上坂先生：失礼します

宮本さん落ち着いた様子で 保健室で休んでます

$<$ Kouchou sensei $>$ : <Hai $>$

[ko:co: sense] [hai?]

'Kepala sekolah' 'Iya'

$<$ Kamisaka sensei> :

$<$ Shitsurei shimasu

[kamisaka sense]

Miyamoto san ochitsuita yousude

hokenshitsu de yasundemasu>

[jitsurei Jimas

miyamoto say ocitsuita yosude

hokenfitsu de yasundemas]

'Guru Kamisaka'

\section{'Permisi}

Miyamoto sudah terlihat lebih tenang dan sekarang sedang beristirahat di ruang perawat'

(Ohitorisama, episode 3 menit ke-24:41)

Shitsurei shimasu/shitsurei suruyo merupakan sapaan salam yang juga berartikan 'permisi' dalam bahasa Indonesia. 
Salam shitsurei shimasu biasanya dituturkan oleh seorang penutur yang hendak memasuki sebuah ruangan atau rumah seseorang. Hal ini dicontohkan pada data percakapan di atas, yang mana salam shitsurei shimasu digunakan oleh seorang guru pada kepala sekolah. Bersituasikan ketika guru Kamisaka berniat untuk bertemu dengan kepala sekolah di ruangannya, ia pun mengetuk pintu dan tidak lama kepala sekolah pun mengizinkannya masuk dengan ungkapan hai yang berartikan 'iya'. Setelah merasa bahwa kepala sekolah sudah mengizinkannya, guru Kamisaka pun masuk dengan mengucapkan sapaan salam shitsurei shimasu.

Adapun tindak tutur yang dilakukan oleh guru Kamisaka tersebut ialah sangat sopan dan santun. Tuturan salam yang disampaikannya pun juga merupakan salam dalam bentuk formal. Sapaan salam non formal dari shitsurei shimasu ialah shitsurei suruyo. Sapaan shitsurei suruyo sudah dicontohkan pada data percakapan nomor (8). Pada percakapan tersebut salam shitsurei suruyo juga digunakan oleh penutur ketika memasuki rumah seseorang. Meskipun kedua salam tersebut memiliki pengertian dan situasi penggunaannya yang sama, namun tetap ada perbedaan di antara keduanya. Salam shitsurei suruyo jauh terdengar lebih akrab penggunaannya daripada salam shitsurei shimasu. Hal ini juga bergantung pada hubungan yang ada antara si penutur dan mitra tuturnya.

(11) Otsukaresama desu / Otsukaresama deshita

Konteks: ketika para sedang bekerja di sebuah ruangan, tibatiba datang seorang guru lainnya untuk memberikan hasil pekerjaannya.

松村先生: お疲れさまです 写真の用意ができました 沢井先生：私も終わりました $<$ matsumura sensei> :

$<$ Otsukaresama desu persiapan foto sudah selesai'

[matsumura sense]

[otsukaresama des

Jasyin no yoi ga? dekimafta]

$<$ Sawai sensei> : <Watashi

mo owarimashita $>$

[sawai sense]

[watafi mo owarimasta]

'guru Sawai'

'saya juga sudah selesai'

(Ohitorisama, episode 1 menit ke-

25:32)

Otsukaresama desu merupakan sapaan salam yang berada di lingkunga pekerjaan. Secara umum, dalam bahasa Indonesia salam ini memiliki makna 'terima kasih atas pekerjaan anda'. Ada banyak makna yang terkandung pada salam tersebut. Selain terima kasih atas pekerjaan, salam tersebut juga digunakan untuk mengekpresikan betapa lelahnya bekerja dan bersyukur karena pekerjaan tersebut telah selesai dilakukan pada hari itu.

Berdasarkan pada contoh data percakapan di atas, salam otsukaresama desu digunakan oleh seorang guru pada rekan sesama guru yang bernama Sawai. Bersituasikan ketika para guru sedang bekerja di sebuah ruangan, tiba-tiba datang seorang guru lainnya untuk memberikan hasil pekerjaannya sambil mengucapkan salam otsukaresama desu. Salam tersebut dituturkan dengan maksud untuk menginformasikan pada guru lainnya bahwa pekerjaannya sudah selesai dilakukan. Sapaan otsukaresama desu juga dapat dituturkan berbeda yaitu otsukaresama deshita. Kedua salam tersebut memiliki pengertian dan maksud yang sama. Meskipun terdapat sedikit perbedaan pada akhiran $\sim$ desu dan deshita. Pengertian dari kedua akhiran tersebut ialah sama. Perbedaannya ialah desu digunakan pada kalimat bentuk sekarang dan akan datang, sedangkan deshita digunakan pada kalimat bentuk lampau.

(12) Gorukosama

Shashin no youi ga dekimashita $>$ 
Konteks: ketika jam sekolah telah berakhir, tiba-tiba kepala sekolah memasuki ruang guru Akiyama untuk menanyakan suatu hal.

秋山先生: 校長先生

校長先生: ああ〜 ご 苦労さま. 間に合いそう?

$<$ Akiyama sensei> :

$<$ Kouchou sensei $>$

[akiyama $s \varepsilon n s \varepsilon$ ]

[ko:co: sense]

'guru Akiyama'

'Kepala sekolah'

$<$ Kouchou sensei $>$ : $<\mathrm{Aa}$

gokurosama. Maniaisou ?>

[ko:co: sense] [a

gokurosama. maniaiso]

'Kepala sekolah' 'Ah

kerja bagus hari ini. Anda

pasti akan berhasil'

(Ohitorisama, episode 1 menit ke- 19:12)

Gokurosama merupakan sapaan salam yang juga memiliki pengertian dan maksud yang sama dengan otsukaresama desu, yaitu terima kasih dan kerja bagus untuk hari ini. Dalam tuturan masyarakat Jepang, sapaan salam seperti ini sangatlah berperan penting untuk menjaga adanya sikap baik dalam komunikasi di lingkungan pekerjaan. Pada data percakapan di atas, sapaan salam ini digunakan oleh seorang kepala sekolah pada salah satu guru yang bernama Akiyama. Bersituasikan ketika jam sekolah telah berakhir, tiba-tiba kepala sekolah memasuki ruang guru dan menyapa guru Akiyama dengan salam gokurosama. Adapun faktor penyebab digunakannya salam ini ialah situasi dan konteks yang ada pada tuturan tersebut, yang mana terjadi ketika jam bekerja telah selesai.

(13) Gomen kudasai

Konteks: Ketika Katsuo beserta istrinya datang mengunjungi rumah keluarga Nakata.

克夫 :ごめんください
洋子 :あつおじ様達！

どうぞ。

$<$ Katsuo $>$

$<$ Gomen kudasai $>$

[katsuo]

[gomen kudasai]

'Permisi'

$<$ Youko $>$ : $<$ A' ojisama

tachi! douzo $>$

[yo:ko] [a? ojisama taci dozo?]

'Ah paman dan semuanya ! silahkan'

(Seigi no mikata, episode 10 menit ke-

29:58)

Gomen kudasai merupakan sapaan salam yang juga dapat berartikan 'permisi' dalam bahasa Indonesia. Pada data percakapan di atas, sapaan salam ini digunakan oleh penutur bernama Matsuo pada anak keluarga Nakata yang bernama Youko. Bersituasikan ketika Katsuo beserta istrinya datang mengunjungi rumah keluarga Nakata dan mengucapkan salam gomen kudasai pada Youko. Sapaan ini dipilih sebagai bentuk rasa hormat penutur ketika bertamu ke rumah seseorang. Sapaan salam ini mengandung makna permintaan maaf karena akan mengganggu waktu sang pemilik rumah. Hal ini dapat dilihat dari pengertian kata gomen yaitu maaf, sedangkan kudasai dapat diartikan dengan please dalam bahasa Inggris. Dalam tuturan masyarakat Jepang sesungguhnya salam ini digunakan untuk bertamu pertama kali ke rumah seseorang yang tidak dikenal atau tidak diketahui namanya. Sapaan ini ditujukan untuk memanggil seseorang yang berada di dalam rumah. Gomen kudasai biasanya sering dituturkan oleh seorang pengantar pos, jasa delivery, dan lainnya.

(14) Hajimemashite

Konteks: ketika Naoki mendatangi rumah keluarga Nakata dan memperkenalkan dirinya

良川:はじめまして良 川直紀です。

$<$ Yoshikawa> : <Hajimemashite

Yoshikawa naoki desu> 
[yofikawa]: [hajimemaste

yofikawa naoki des]

'Pertama-tama perkenalkan saya

Yoshikawa Naoki'

(Seigi no mikata, episode 5 menit ke30:59)

Hajimemashite merupakan sapaan salam yang digunakan ketika akan memperkenalkan diri pada mitra tuturnya. Sapaan ini berartikan 'pertama-tama perkenalkan' dalam bahasa Indonesia. Pada data percakapan di atas, salam ini digunakan oleh seorang penutur bernama Yoshikawa pada Haruko. Bersituasikan ketika Katsuo beserta istrinya datang mengunjungi rumah keluarga Nakata, tibatiba Naoki datang dan langsung memperkenalkan diri dengan keluarga Nakata dengan salam hajimemashite.

\section{Ranah dan Faktor Penggunaan Salam Sebagai Ungkapan Sapaan}

Ranah penggunaan salam sebagai ungkapan sapaan ialah berada pada lingkungan keluarga, lingkungan pekerjaan, dan lingkungan umum. Pada lingkungan keluarga, selain menggunakan sapaan nomina kekerabatan sering pula digunakan sapaan berupa salam seperti ohayou, tadaima kaerimashita dan itte mairimasu. Salam sapaan tersebut dapat terjadi antara sesama anggota keluarga yakni suami dengan istri ataupun, anak dengan orang tuanya. Pada lingkungan pekerjaan, salam sapaan yang sering digunakan ialah cenderung bersifat formal, yang mana sapaan dapat terjadi antara bawahan dengan atasan atapun antar sesama karyawan. Sedangkan pada lingkungan umum, sapaan yang sering digunakan ialah bersifat formal misalnya seperti penggunaan salam sapaan ohayou gozaimasu dan irrashaimase.

Variasi salam sebagai ungkapan sapaan dalam ranah penggunaan sapaan ialah dipengaruhi oleh beberapa faktor yang berkaitan dengan lawan tutur (meliputi: hubungan kekerabatan, hubungan non kekerabatan, usia, status sosial, gender), waktu, tempat, dan situasi/peristiwa tutur. Faktor-faktor tersebut mempengaruhi tingkat kesantunan pada ungkapan sapaan, yang mana dapat dikatakan santun jika dalam penggunaannya ialah menggunakan bahasa formal. Pada penuturan ungkapan sapaan juga digunakan strategi kesantunan langsung tanpa basa-basi, yang mana strategi ini dipilih berdasarkan pada keadaan dan situasi tuturan tersebut.

\section{PENUTUP}

Berdasarkan uraian dan pembahasan mengenai penggunaan salam sebagai ungkapan sapaan pada tuturan masyarakat Jepang dalam drama Seigi no mikata dan Ohitorisama, ditemukan sebanyak 14 salam sapaan yakni: sapaan ohayou gozaimasu/ohayou, konnichiwa, dan konbanwa dapat dituturkan oleh semua penutur baik perempuan maupun laki-laki di berbagai kalangan. Salam irasshaimase/ rassai dituturkan oleh seorang pedagang/ pelayan di tempat-tempat perbelanjaan. Salam iite mairimasu/iite kuruyo, tadaima/tadaima kaerimashita, okaeri, ojama shiteirundane, sumimasen/suimasen, shitsurei shimasu/shitsurei suruyo dapat dituturkan oleh semua penutur. Kemudian pada salam otsukaresama desul otsukaresama deshita dan gokurosama dituturkan oleh semua penutur yang berada dilingkungan kerja. Selanjutnya pada salam gomen kudasai dan hajimemashite juga dapat dituturkan oleh semua penutur. Adapun variasi salam tersebut dapat terjadi di lingkungan keluarga, pekerjaan, dan lingkungan umum yang dipengaruhi oleh beberapa faktor yang dapat berkaitan dengan lawan tutur, waktu, tempat, dan situasi/peristiwa tutur. Sedangkan strategi kesantunan yang sering digunakan ialah strategi kesantunan langsung tanpa basa basi. Sebuah tuturan dapat dikatakan santun jika digunakannya bahasa formal dalam tuturan tersebut.

\section{DAFTAR PUSTAKA}

Brown, Penelope dan Levinson, Stephen. (1987). Politeness: Some 
Universal in Language Usage. Cambridge: Cambridge University Press.

Hirabayashi, Yoshisuke dkk. (1992). Gaikokujin no Tame no Nihonggo Reibun/Mondai shi-rizu : Keigo. Tokyo: Aratake Shuppan.

Holmes, Janet. (2001). An Introduction to Sociolinguistic Learning About Language. New York: Pearson Longman.

Kridalaksana, Harimurti. (1982). Dinamika Tutur Sapa dalam Bahasa Indonesia. Jakarta: Bhratara.

Makino, Seichi. (1996). Uchi to soto no gengo bunkagaku. Tokyo: Aruku.

Matsuura, Kenji. (1994). Kamus Bahasa Jepang-Indonesia. Kyoto: Kyoto Sangyo University Press.

Mizutani, Osamu. (1979). Hanashi Kotoba to Nihonjin. Tokyo: Sotakusha.
Mizutani, Osamu. (1983). Hanashi Kotoba no Hyogen. Tokyo: Chikuma Shobou.

Niyekawa, Agnes M. (1991). Minimum essential politeness: A guide to Japanese honorifics language. Tokyo: Kondansha.

Nomoto, Kikuo. (1994). Kamus Pemakaian Bahasa Jepang Dasar. Tokyo: Kokuritsu Kokugo Kenkyuusho.

Usami, Mayumi. (2002). Discourse politeness in Japanese conversation. Tokyo:

Hitsuji Shobo.

\section{Elektronik}

http://d-addicts.com/ (diakses pada tanggal 25 Oktober 2016)

kbbi.web.id/ (diakses pada tanggal 12 Maret 2017) 